\title{
Role of IL-22 in persistent allergic airway diseases caused by house dust mite: a pilot study
}

\author{
Laura Tamasauskiene*, Vilte Marija Gintauskiene, Daina Bastyte and Brigita Sitkauskiene
}

\begin{abstract}
Background: Persistent allergic airway diseases cause a great burden worldwide. Their pathogenesis is not clear enough. There is evidence that one of the recently described cytokine interleukin (IL) 22 may be involved in the pathogenesis of these diseases. Scientists argue if this cytokine acts as proinflammatory or anti-inflammatory agent. The aim of this study was to investigate IL-22 level in patients with persistent allergic airway diseases caused by house dust mite (HDM) in comparison with healthy individuals and to evaluate its relationship with IL-13 and IL-10 level, symptoms score and quality of life.

Methods: Patients with persistent allergic rhinitis caused by HDM and having symptoms for at least 2 years with or without allergic asthma were involved into the study. Measurements of IL-22, IL-13 and IL-10 and in serum and nasal lavage was performed by ELISA. Questionnaires assessing symptoms severity and quality of life were used.

Results: A tendency was observed that IL-22 in serum and nasal lavage was higher in patients with allergic airway diseases compared to control group $(14.86 \mathrm{pg} / \mathrm{ml}$ vs. $7.04 \mathrm{pg} / \mathrm{ml}$ and $2.67 \mathrm{pg} / \mathrm{ml} \mathrm{vs.} 1.28 \mathrm{pg} / \mathrm{ml}$, respectively). Positive statistically significant correlation was estimated between serum IL-22 and serum IL-10 ( $\mathrm{rs}=0.57, p<0.01$ ) and IL-13 ( $r s=0.44, p<0.05)$ level. Moreover, positive significant correlation was found between IL-22 in nasal lavage and IL-10 in nasal lavage ( $\mathrm{rs}=0.37, p<0.05)$. There was a negative statistically significant correlation between serum IL-22 and Rhinoconjunctivitis Quality of Life Questionnaire (RQLQ) ( $r s=-0.42, p<0.05$ ).
\end{abstract}

Conclusion: Our study showed a possible anti-inflammatory effect of IL-22 in patients with persistent allergic airway diseases caused by HDM.

Keywords: Persistent allergic airway diseases, Allergic asthma, Allergic rhinitis, House dust mite, IL-22

\section{Background}

Allergic airway diseases-allergic rhinitis and allergic asthma-cause a great burden worldwide [1-5]. The main allergen which is responsible for the persistent allergic rhinitis and allergic asthma is house dust mite (HDM) [6]. The prevalence of allergic airway diseases increases despite modern methods of treatment and better access to them $[1,5,7]$. However, the pathogenesis

*Correspondence: laura.tamasauskiene@lsmu.lt

Department of Immunology and Allergology, Lithuanian University

of Health Sciences, Eiveniu str. 2, 50009 Kaunas, Lithuania of these diseases is still under investigation. Allergic rhinitis and allergic asthma are heterogenous diseases and manifest in different phenotypes which may depend on endotypes $[1,8]$. Moreover, allergic rhinitis and allergic asthma very often are diagnosed together, that is why the hypothesis of united airway disease was proposed $[9,10]$.

For better management of allergic airway diseases, it is particularly important to determine its phenotype and endotype. This can ensure personalized approach, treatment options and prognosis for current patient especially when common medications are not effective enough. However, there is no unified classification of 
phenotypes and endotypes of allergic airway diseases. That is why scientists are still investigating immunologic mechanisms that can be important in the development of allergic rhinitis and allergic asthma.

Cell-mediated effector immunity can be divided in three types: type 1, type 2, and type 3 [11]. It is known that in allergic airway diseases the main role belongs to T lymphocyte helper (Th) 2 producing interleukin (IL) 4, IL-5 and IL-13 (type 2 immunity) [1, 8, 11]. Type 1 immunity consists of Th1 and its produced cytokines such as interferon $-\gamma$ (IFN $-\gamma$ ) and type 3 immunity consists of Th17 cells producing IL-17 and IL-22 [11]. It is thought that type 1 and type 3 immunity is important in the development of autoimmune disorders or chronic non-allergic airway inflammation [11, 12]. However, there are evidences that IL-22 can also be involved in allergic airway inflammation [13-16].

IL-22 was firstly described in 2000 [17]. Initially it was thought that it is secreted only by Th17, however, later a new $\mathrm{T}$ cell subpopulation Th22 was found [18, 19]. Now it is known that IL-22 can be secreted by Th1, Th2, Th17, Th22, natural killers, and innate lymphoid cells [20]. Despite the evidence that IL-22 can be important in the pathogenesis of allergic asthma and allergic rhinitis scientists argue if this cytokine acts as proinflammatory or anti-inflammatory agent $[14,21]$.

The aim of this study was to investigate IL-22 level in patients with persistent allergic airway diseases caused by HDM in comparison with healthy individuals and to evaluate its relationship with IL-13 and IL-10 level, symptoms score and quality of life.

\section{Methods}

\section{Study population}

Patients with persistent allergic rhinitis diagnosed according to Allergic Rhinitis and its Impact on Asthma (ARIA) and having symptoms for at least 2 years with or without allergic asthma diagnosed according Global Initiative for Asthma (GINA) were involved into the study. The inclusion criteria were hypersensitivity to HDM diagnosed by skin prick test or allergen specific immunoglobulin (Ig) E test, no use of local or systemic glucocorticoids or other immunosuppressant drugs for at least 1 month before the study, no use of antihistamines for 1 week before the study and no respiratory infection for at least 1 month before the study. Exclusion criteria were treatment with allergen immunotherapy, relevant hypersensitivity to other inhaled aeroallergens, malignant diseases and systemic autoimmune or other diseases. Healthy patients were involved into the study as the control group.
Patients additionally were divided into three groups: (1) allergic rhinitis, (2) allergic rhinitis with allergic asthma and (3) control group.

\section{Questionnaires}

Patients with allergic rhinitis were asked to complete Total nasal symptom score (TNSS) [22] and Rhinoconjunctivitis Quality of Life Questionnaire (RQLQ) [23].

Patients with allergic asthma additionally were asked to complete Asthma control test (ACT) [24] and Asthma Quality of Life Questionnaire (AQLQ) [25].

All subjects had to complete Pittsburgh Sleep Quality Index (PSQI) [26].

The permission to use validated questionnaires (Lithuanian versions) was received.

\section{Evaluation of allergic sensitization}

Allergic sensitization was determined by skin prick test or allergen specific IgE test.

Skin prick test was performed according to the standard protocol with standard inhalant allergens (Diater, Spain) on the inner forearm. Drop of different allergen solution was placed at $3 \mathrm{~cm}$ distant from each other. Histamine solution $10 \mathrm{mg} / \mathrm{ml}$ was used as a positive control and diluent was used as a negative control. The skin was pricked through the drop using the tip of a lancet (separate lancet was used for all allergen drops). Skin reaction was assessed after $15 \mathrm{~min}$. Wheal was measured using ruler. The test was assumed as a 'positive' if diameter of the wheal was at least $3 \mathrm{~mm}$.

Measurement of allergen specific IgE was performed using standard immunoblot analysis according to the manufacturer's instructions (Euroimmun, Germany). Total IgE in serum was measured using enzyme immunoassays (AIA-FAC IgEII Tosoh Bioscience, Japan).

\section{Peripheral blood collection and processing}

Peripheral vein puncture was performed for all subjects. Blood samples were drawn into KEDTA tubes for investigation for complete blood count and into serum tubes. Serum tubes were stored at room temperature for 30-60 min. and centrifuged at $3500 \mathrm{rpm}$ for $10 \mathrm{~min}$, and serum was separated and frozen at $-80{ }^{\circ} \mathrm{C}$ for further analysis.

\section{Nasal lavage collection and processing}

Nasal lavage was collected for all subjects using $5 \mathrm{ml}$ isotone saline per nostril with reclined neck (about $30{ }^{\circ} \mathrm{C}$ from the horizontal) and closed soft palate. After $30 \mathrm{~s}$ the subject flexed the neck draining lavage fluid into a sterile vessel. Nasal lavage fluid was frozen at $-80^{\circ} \mathrm{C}$ for further analysis. 


\section{Nasal smear for eosinophil detection}

Nasal smears of patients were obtained by gently swabbing the nasal inferior turbinate with a cotton-tipped swab. The sample was then placed on a surface of glass microscope slide and stained with Giemsa stain. All specimens were examined by qualified pathologist.

\section{Laboratory analysis of cytokines}

Measurements of IL-22, IL-13, and IL-10 and in serum and nasal lavage was performed by ELISA using commercial kits (Elabscience Biotechnology Inc., USA).

\section{Statistical methods}

Statistical analysis was performed using statistical program SPSS 20. Non-parametric statistical methods were applied.

Mann-Whitney $\mathrm{U}$ and Kruskal-Wallis $\mathrm{H}$ tests were applied for comparison of variables between patients with allergic airway diseases and healthy individuals, and between patients with allergic rhinitis only, patients with allergic rhinitis and allergic asthma and healthy individuals.

Methods of correlation (Spearman's coefficient) was used to find associations between IL-22 and IL-13, IL-10, eosinophil count, neutrophil count, lymphocyte count, total IgE, TNSS, ACT, AQLQ, RQLQ and PSQI.

A $p$ value of $<0.05$ was considered statistically significant.

\section{Results}

\section{Characteristics of studied subjects}

Fourty subjects were involved into the study. Demographic characteristics are presented in Table 1. Subjects' distribution according to the age and sex did not differ between different groups. Duration of rhinitis symptoms was slightly longer in patients with allergic rhinitis and allergic asthma compared with patients with allergic rhinitis only. Majority of patients with allergic airway diseases caused by HDM had sensitivity to other inhalant allergens.

There were no differences of TNSS, RQLQ and PSQI scores between patients with allergic rhinitis and allergic asthma and patients with allergic rhinitis only (Table 1 ). PSQI also did not differ significantly between patients with allergic airway diseases and healthy individuals.

\section{Blood cells and serum IgE}

There were no statistically significant differences between leukocytes, neutrophils, lymphocytes, and monocytes count in blood between studied groups (Table 2). Whereas blood eosinophil count and total IgE level in serum were statistically significantly higher in patients with allergic airway diseases than in healthy individuals (Table 2).

Table 2 Total blood count, serum total IgE and eosinophils in nasal smear

\begin{tabular}{|c|c|c|}
\hline & $\begin{array}{l}\text { Patients with allergic } \\
\text { airway diseases } \\
(\mathrm{N}=31)\end{array}$ & Control group $(n=9)$ \\
\hline Leukocytes, $\times$ 10/9/l & $6.22 \pm 0.30$ & $6.19 \pm 0.37$ \\
\hline Neutrophils $\times 10 / 9 / l$ & $3.38 \pm 0.18$ & $3.78 \pm 0.37$ \\
\hline Lymphocytes $\times 10 / 9 / 1$ & $2.07 \pm 0.17$ & $1.78 \pm 0.12$ \\
\hline Monocytes × 10/9/I & $0.53 \pm 0.03$ & $0.46 \pm 0.03$ \\
\hline Eosinophils $\times 10 / 9 / /$ & $0.25 \pm 0.03^{*}$ & $0.13 \pm 0.04$ \\
\hline Total IgE, kU/l & $269.26 \pm 50.60^{* *}$ & $34.83 \pm 20.26$ \\
\hline
\end{tabular}

${ }^{*} p<0.05$ compared with control group

** $p<0.01$ compared with control group

Data are presented as mean \pm SEM

Table 1 Demographic characteristics and responses to questionnaires of study population

\begin{tabular}{|c|c|c|c|}
\hline & \multicolumn{2}{|c|}{ Patients with allergic airway diseases $(\mathrm{N}=31)$} & \multirow[t]{2}{*}{ Control group $(n=9)$} \\
\hline & $\begin{array}{l}\text { Patients with allergic } \\
\text { rhinitis }(N=22)\end{array}$ & $\begin{array}{l}\text { Patients with allergic rhinitis } \\
\text { and allergic asthma }(\mathrm{N}=9)\end{array}$ & \\
\hline Male/female, N & $10 / 12$ & $4 / 5$ & $2 / 7$ \\
\hline Age, years, mean \pm SEM & $27.27 \pm 1.54$ & $29.44 \pm 2.99$ & $34.33 \pm 4.71$ \\
\hline Duration of rhinitis symptoms, years, mean \pm SEM & $13.33 \pm 1.89$ & $16.00 \pm 3.84$ & $\mathrm{~N} / \mathrm{A}$ \\
\hline Duration of asthma symptoms, years, mean \pm SEM & $\mathrm{N} / \mathrm{A}$ & $11.20 \pm 5.90$ & N/A \\
\hline Hypersensitivity to other aeroallergens, N (\%) & $15(75.00)$ & $7(77.80)$ & N/A \\
\hline TNSS, mean \pm SEM & $4.32 \pm 0.55$ & $3.88 \pm 0.74$ & N/A \\
\hline $\mathrm{ACT}$, mean $\pm \mathrm{SEM}$ & $\mathrm{N} / \mathrm{A}$ & $19.5 \pm 1.10$ & N/A \\
\hline $\mathrm{RQLQ}$, mean $\pm \mathrm{SEM}$ & $1.61 \pm 0.24$ & $1.48 \pm 0.50$ & N/A \\
\hline$A Q L Q$, mean \pm SEM & $\mathrm{N} / \mathrm{A}$ & $5.62 \pm 0.40$ & $\mathrm{~N} / \mathrm{A}$ \\
\hline PSQI, mean \pm SEM & $7.05 \pm 0.76$ & $6.50 \pm 1.64$ & $5.67 \pm 0.62$ \\
\hline
\end{tabular}




\section{Eosinophils in nasal smear}

Eosinophil count in nasal smear did not differ significantly between patients with allergic airway diseases and healthy individuals $(2.67 \pm 0.64 \%$ vs. $0.25 \pm 0.16 \%)$. However, a tendency was observed that eosinophil count in nasal smear is higher in patients with allergic airway diseases than in subjects from control group $(p=0.06)$.

\section{Cytokines level in serum and nasal lavage}

No statistically significant differences of IL-22, IL-13 and IL-10 level in serum and nasal lavage were found between patients with allergic airway diseases and control group (Fig. 1). However, a tendency was observed that IL-22 in serum and nasal lavage was higher in patients with allergic airway diseases compared to control group (Fig. 1).

\section{Correlation between IL-22 and IL-10, IL-13 and scores of symptoms and quality of life}

Positive statistically significant correlation was estimated between serum IL-22 and serum IL-10 and IL-13 level (Fig. 2a, b). Moreover, positive significant correlation was found between IL-22 in nasal lavage and IL-10 in nasal lavage (Fig. 2d). However, there was no relation between IL-22 level in nasal lavage and IL-22 level in serum $(\mathrm{rs}=-0.19, p=0.31)$.

There was a negative statistically significant correlation between serum IL-22 and RQLQ (Table 3). However, there were no correlations between serum IL-22 level and TNSS, AQLQ and ACT. IL-22 in nasal lavage also did not correlated with any score of used questionnaires (Table 3).

There was a negative correlation between leukocytes count in blood and IL-22 level in nasal lavage, however, no other correlations between IL-22 level in serum and nasal lavage and serum total IgE, leukocytes subpopulations in blood and eosinophils in nasal smear (Table 4). IL-22 level in nasal lavage negatively correlated with eosinophil count in nasal smear in patients with allergic rhinitis and allergic asthma $(\mathrm{rs}=-0.83, p<0.05)$. Moreover, in this patients' group negative correlation was also estimated between IL-22 level in nasal lavage and IL-22 level in serum $(\mathrm{rs}=-0.70, p<0.05)$.

\section{Discussion}

Our study showed a tendency that local and systemic IL-22 level was increased in patients with allergic airway diseases caused by HDM. Both IL-22 level in serum and IL-22 level in nasal lavage were positively associated with IL-10 level in serum and nasal lavage. Our findings support hypothesis of anti-inflammatory effect of IL-22 in persistent allergic airway diseases. However, experimental, and clinical studies provide controversial data about possible role of IL-22 in these diseases [14, 21].

Our findings are in agreement with the majority of clinical studies investigating IL-22 level in patients with allergic rhinitis and/ or allergic asthma and revealed
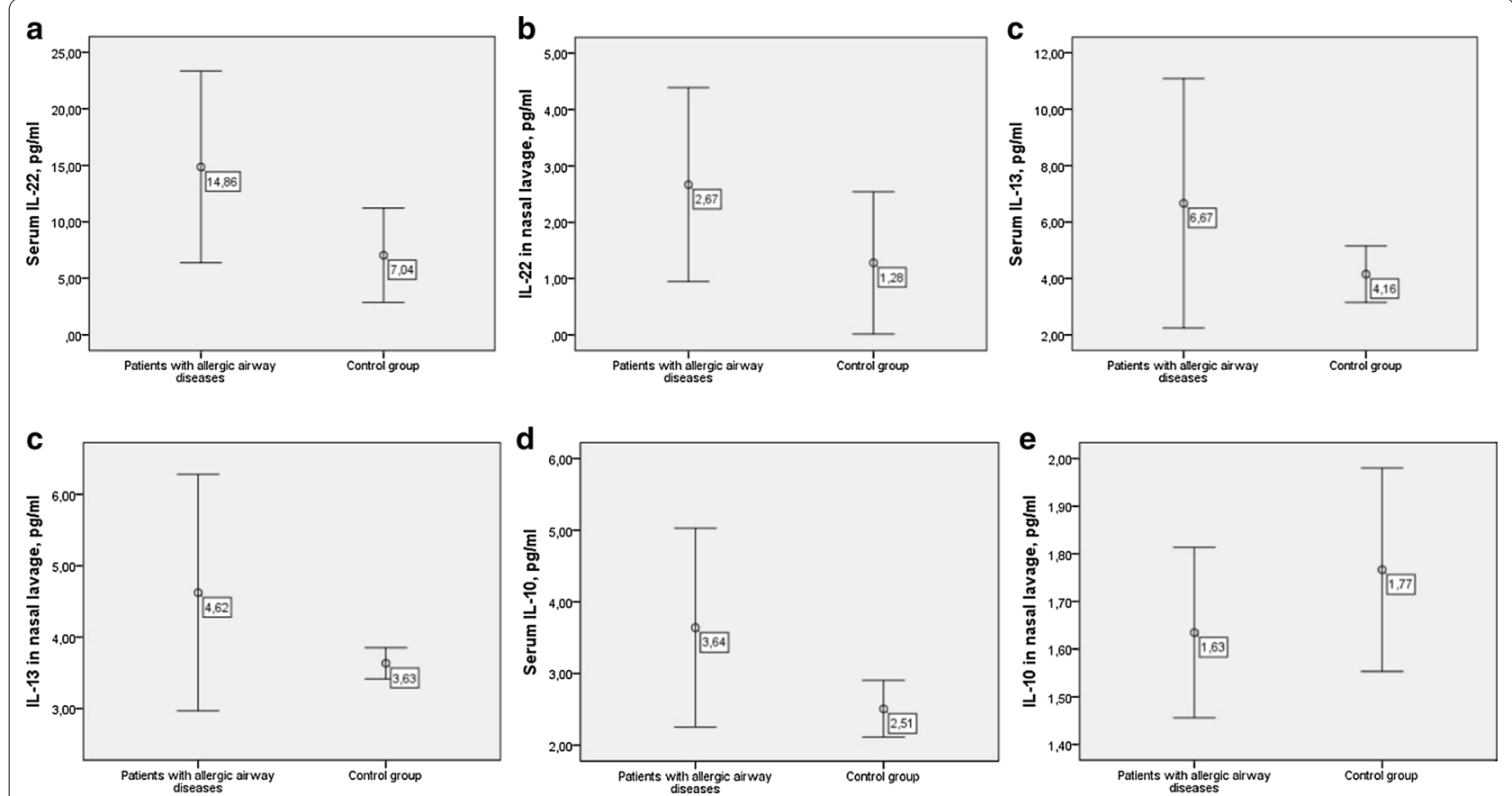

Fig. 1 IL-22, IL-10 and IL-13 level in serum and nasal lavage in patients with allergic airway diseases and healthy individuals 


\section{a}

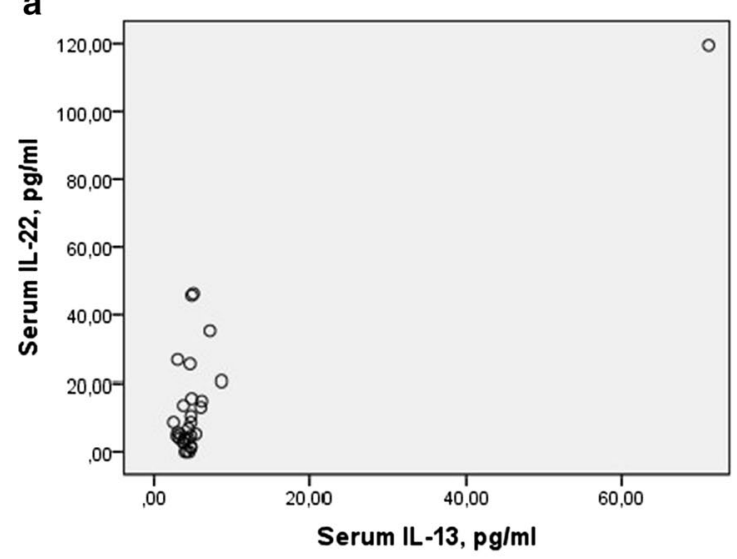

C

C

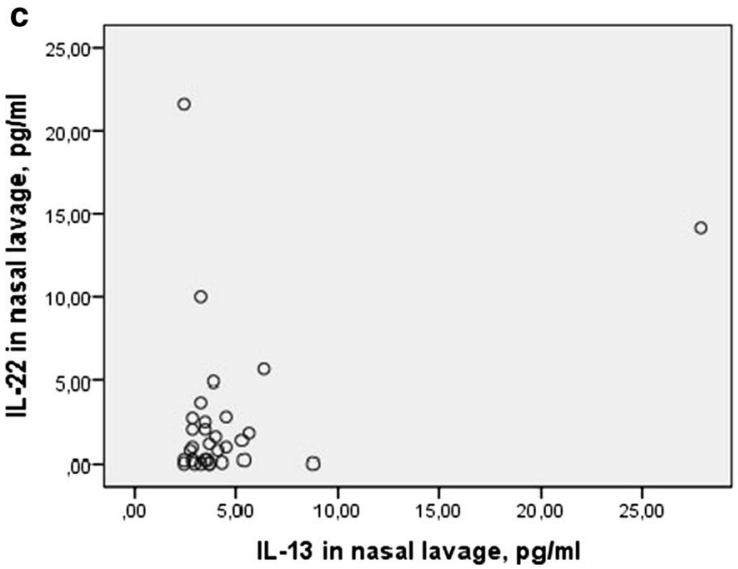

b

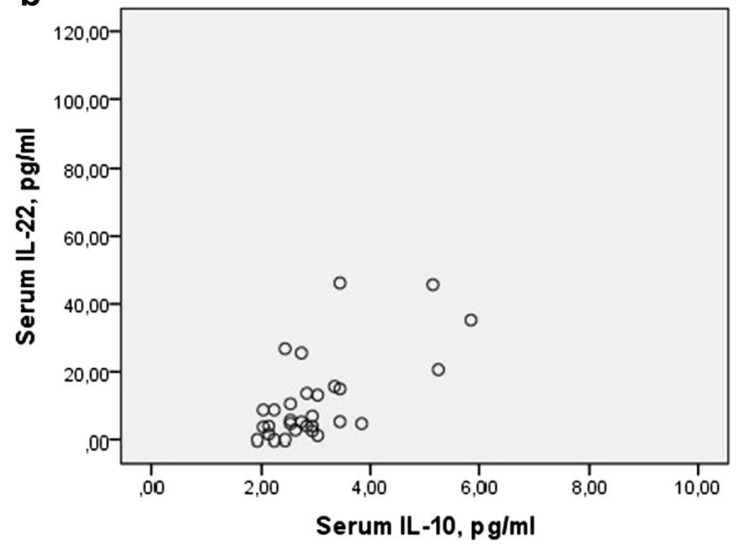

d

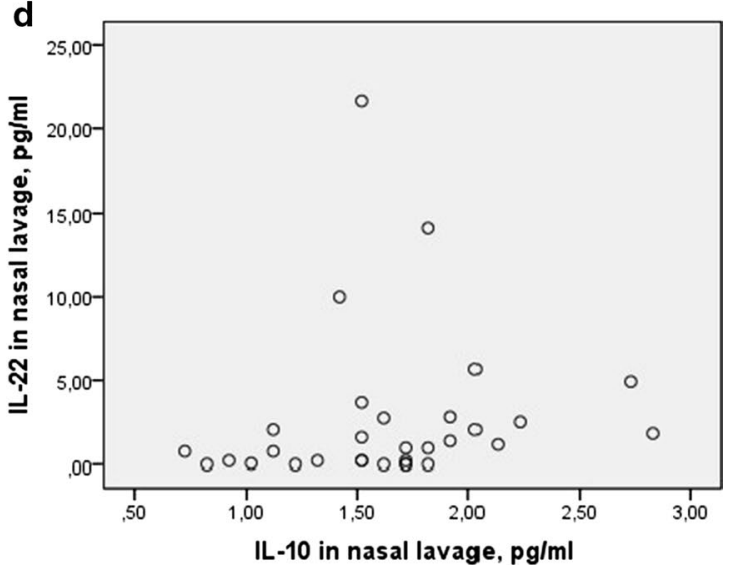

Fig. 2 Spearman's correlation between IL-22, IL-10 and IL-13 in serum and nasal lavage in patients with allergic airway diseases. a rs $=0.44, p<0.05$, b rs $=0.57, p<0.01, \mathbf{c r s}=0.1, p>0.05, \mathbf{d} r s=0.37, p<0.05$

Table 3 Spearman's correlation between IL-22 and TNSS, $A C T, R Q L Q, A Q L Q$ and PSQI in patients with allergic airway diseases

\begin{tabular}{lcc}
\hline & Serum IL-22 & $\begin{array}{l}\text { IL-22 } \\
\text { in nasal } \\
\text { lavage }\end{array}$ \\
\hline TNSS & -0.22 & -0.12 \\
ACT & 0.27 & 0.08 \\
RQLQ & $-0.42^{*}$ & 0.11 \\
AQLQ & 0.66 & -0.15 \\
PSQ & -0.14 & 0.14 \\
\hline
\end{tabular}

${ }^{*} p<0.05$

that concentration of IL-22 in serum or plasma was higher in these patients than in healthy subjects [2732]. Though, studies investigating local IL-22 level provided controversial results. For example, Shahsavan et al. found that the gene expression level of IL-22 in
Table 4 Spearman's correlation between IL-22 and inflammatory markers in patients with allergic airway diseases

\begin{tabular}{lcl}
\hline & Serum IL-22 & $\begin{array}{l}\text { IL-22 } \\
\text { in nasal } \\
\text { lavage }\end{array}$ \\
\hline Total lgE, kU/l & 0.08 & -0.03 \\
Leukocytes, $\times 10 / 9 / 1$ & 0.15 & $-0.37^{*}$ \\
Neutrophils $\times 10 / 9 / 1$ & 0.12 & -0.30 \\
Lymphocytes $\times 10 / 9 / 1$ & 0.06 & -0.28 \\
Monocytes $\times 10 / 9 / 1$ & 0.12 & -0.32 \\
Eosinophils $\times 10 / 9 / 1$ & 0.11 & -0.20 \\
Eosinophils in nasal smear (\%) & -0.02 & -0.21 \\
\hline${ }^{*} p<0.05$ & &
\end{tabular}

human nasal mucosa was higher in patients with persistent allergic rhinitis than in healthy individuals [28]. In contrary, Andersson et al. analysed IL-22 level in 
childrens' with severe asthma bronchoalveolar lavage and did not found differences between asthma group and control group [31]. However, there are more evidence that IL-22 level is higher in patients with allergic airway diseases. Differences between studies can occur due to relatively small studies samples and different methods used for investigation of IL-22 level.

In our study level of IL-22 was positively related with IL-10 despite local or systemic. This supports hypothesis of anti-inflammatory effect of IL-22. We found positive correlation between local and systemic IL-22 level and local and systemic IL-10 level. We did not find any clinical study investigating relationship between IL-22 and other proinflammatory and anti-inflammatory cytokines in allergic airway diseases in PubMed database. But experimental studies revealed that IL-22-positive mice had a lower level of IL-13 in the bronchoalveolar lavage after ovalbumin stimulation in comparison with IL-22-negative mice [33, 34]. Nakagome et al. showed that IL-22-producing plasmid vector that was delivered before the sensitization with ovalbumin suppressed eosinophilic airway inflammation and increased the level of IL-10 [35]. However, other study showed that ovalbumin-challenged and IL-22-deficient mice had low level of IL-5, IL-13 and IL-33 [36]. It is thought that IL-22 plays its role via subsequent Janus kinase-signal transducers and activators of transcription (JAK-STAT) signaling pathways [37].

Our study showed that IL-22 level in nasal lavage negatively correlated with eosinophil count in nasal smear in patients with allergic rhinitis and allergic asthma. In contrary, Shahsavan et al. revealed positive link between serum IL-22 level and eosinophil count in nasal mucosa [28]. However, IL-22 level in serum may not reflect the local IL-22 level and this could be the reason for controversial data. Some experimental studies showed that ovalbumin-challenged and IL-22-deficient mice had a low level of eosinophils in bronchoalveolar lavage and lung tissue and reduced leukocyte infiltration [36]. In contrary, some other studies with animals reported that after ovalbumin stimulation IL-22-positive mice had a reduced number of eosinophils in the bronchoalveolar lavage when compared with IL-22-negative mice [33, 34]. Moreover, Besnard et al. suggested that IL-22 may play dual role in allergic airway inflammation-it may be necessary for the induction of inflammation, but during continuous allergen challenge, the lack of IL-22 may exacerbate allergic inflammation [36]. In contrary, Nakagome et al. presented that IL-22 could have an immunosuppressive effect during the early stage of an immune response by reducing eosinophilic airway inflammation [35]. The differences between the results from different studies could be explained by different conditions and methods of experiments.

We did not find significant correlation between IL-22 in serum and IL-22 in nasal lavage. Interestingly, we found negative correlation between serum IL-22 level and IL-22 level in nasal lavage only in patients with allergic rhinitis together with allergic asthma. These findings suggest that systemic IL-22 level may not reveal local IL-22 concentration. We did not find other studies investigating relation between local and systemic IL-22 level in allergic airway diseases.

Our study revealed a negative link between serum IL-22 and RQLQ in patients with allergic airway diseases. In contrast, other two studies performed by Shahsavan et al. and Zhu et al. revealed positive relationship between serum IL-22 and rhinitis and asthma symptoms scores in patients with allergic rhinitis and allergic asthma $[28,30]$. Farfariello et al. found that IL-22 was higher in patients with severe allergic rhinitis and severe allergic asthma than in patients with moderate allergic rhinitis and allergic asthma [29]. Zhao et al. also found that level of IL-22 in plasma was consistently increased with the severity of asthma [32]. Moreover, Sherkat et al. showed a significantly higher level of IL-22 in serum and sputum samples from adults with severe asthma in comparison to patients with moderate asthma [38]. These findings show that IL-22 depends on the disease severity. In contrast, Bayrak Degirmenci et al. did not find any relation between plasma IL-22 and symptoms score in patients with allergic rhinitis [27]. As mentioned before, these differences between studies could be determined by relatively small studies samples, different methods of IL-22 investigation and use of different tools for investigating severity of symptoms.

To our knowledge there are no published articles about IL-22 level in nasal lavage and relation between systemic and local IL-22 level and other cytokines. Moreover, there are lack of articles presenting data about IL-22 link with symptoms score, quality of life and different inflammatory markers in patients with allergic airway diseases.

\section{Conclusions}

Our study showed a possible anti-inflammatory effect of IL-22 in patients with persistent allergic airway diseases caused by HDM.

\section{Abbreviations}

IL: Interleukin; HDM: House dust mite; Th: T lymphocyte helper; ARIA: Allergic Rhinitis and its Impact on Asthma; GINA: Global Initiative for Asthma; Ig: Immunoglobulin; TNSS: Total nasal symptom score; ACT: Asthma control test; RQLQ: Rhinoconjunctivitis Quality of Life Questionnaire; AQLQ: Asthma Quality of Life Questionnaire; PSQI: Pittsburgh Sleep Quality Index. 


\section{Acknowledgements}

Authors would like to express gratitude to Dr. Edita Gasiuniene for her help with involving patients to the study and to Vilte Kristopaityte for her help with preparing blood and nasal lavage samples for further investigation.

\section{Authors' contributions}

LT involved patients into the study, performed clinical investigation, analyzed and interpreted the patient data, performed statistical analysis and was a major contributor in writing the manuscript. VMG and DB performed and evaluated laboratory tests and contributed to explaining the methods of laboratory tests. BS supervised the study and contributed to writing the manuscript. All authors read and approved the final manuscript.

\section{Funding}

Research was partly funded by Research Foundation of Lithuanian University of Health Sciences for financial support (ELISA reagents for detection of interleukins in serum and nasal lavage fluid were purchased). The funding body did not have impact on the design of the study and collection, analysis, and interpretation of data and in writing the manuscript.

\section{Availability of data and materials}

All data generated or analysed during this study are included in this published article.

\section{Ethics approval and consent to participate}

The study was approved by the Regional Bioethics Committee at the Lithuanian University of Health Sciences (No. BE-2-28). Subjects gave their written informed consent.

\section{Consent for publication}

Not applicable.

\section{Competing interests}

The authors declare that they have no competing interests.

Received: 28 September 2020 Accepted: 13 January 2021

Published online: 21 January 2021

\section{References}

1. Asthma Gl for. Global strategy for asthma management and prevention. 2020

2. Blaiss MS, Hammerby E, Robinson S, Kennedy-Martin T, Buchs S. The burden of allergic rhinitis and allergic rhinoconjunctivitis on adolescents: a literature review. Ann Allergy Asthma Immunol. 2018;121(1):43-52.e3. https://doi.org/10.1016/j.anai.2018.03.028.

3. Meltzer EO. Allergic rhinitis: burden of illness, quality of life, comorbidities, and control. Immunol Allergy Clin North Am. 2016;36(2):235-48.

4. Lee LK, Obi E, Paknis B, Kavati A, Chipps B. Asthma control and disease burden in patients with asthma and allergic comorbidities. J Asthma. 2018;55(2):208-19.

5. Broek JL, Bousquet J, Baena-Cagnani CE, Bonini S, Canonica GW, Casale TB, et al. Allergic Rhinitis and its Impact on Asthma (ARIA) guidelines: 2010 Revision. J Allergy Clin Immunol. 2010;126(3):466-76.

6. Li L, Qian J, Zhou Y, Cui Y. Domestic mite-induced allergy: causes, diagnosis, and future prospects. Int J Immunopathol Pharmacol. 2018;32:1-8.

7. Passali D, Cingi C, Staffa P, Passali F, Muluk NB, Bellussi ML. The international study of the allergic rhinitis survey: outcomes from 4 geographical regions. Asia Pacific Allergy. 2018;8(1):1-15

8. Akdis CA, Hellings PW, Agache I. Global atlas of allergic rhinitis and chronic rhinosinusitis. Eur Acad Allergy Clin Immunol. 2015;1:442.

9. Giavina-Bianchi P, Aun MV, Takejima P, Kalil J, Agondi RC. United airway disease: current perspectives. J Asthma Allergy. 2016;9:93-100.

10. Licari A, Castagnoli R, Denicolò CF, Rossini L, Marseglia A, Marseglia GL. The nose and the lung: United Airway Disease? Front Pediatr. 2017:5:44

11. Annunziato F, Romagnani C, Romagnani S. The 3 major types of innate and adaptive cell-mediated effector immunity. J Allergy Clin Immunol. 2015;135(3):626-35.
12. De Greve G, Hellings PW, Fokkens WJ, Pugin B, Steelant B, Seys SF. Endotype-driven treatment in chronic upper airway diseases. Clin Transl Allergy. 2017;7:22.

13. Tamasauskiene $L$, Sitkauskiene B. Interleukin-22 in allergic airway diseases: a systematic review. J Interf cytokine Res Off J Int Soc Interf Cytokine Res. 2020;40(3):125-30.

14. Tamasauskiene L, Sitkauskiene B. Role of Th22 and IL-22 in pathogenesis of allergic airway diseases: pro-inflammatory or anti-inflammatory effect? Pediatr Neonatol. 2018:59(4):339-44.

15. Leyva-Castillo JM, Yoon J, Geha RS. IL-22 promotes allergic airway inflammation in epicutaneously sensitized mice. J Allergy Clin Immunol. 2019;143(2):619-630.e7.

16. Hirose $\mathrm{K}$, Ito T, Nakajima H. Roles of IL-22 in allergic airway inflammation in mice and humans. Int Immunol. 2018;30(9):413-8.

17. Dumoutier L, Van Roost E, Ameye G, Michaux L, Renauld JC. IL-TIF/IL-22: genomic organization and mapping of the human and mouse genes. Genes Immun. 2000;1 (8):488-94.

18. Eyerich S, Eyerich K, Pennino D, Carbone T, Nasorri F, Pallotta S, et al. Th22 cells represent a distinct human $T$ cell subset involved in epidermal immunity and remodeling. J Clin Invest. 2009:119(12):3573-85.

19. Jia $L$, Wu C. The biology and functions of Th22 cells. Adv Exp Med Biol. 2014;841:209-30.

20. Eyerich K, Eyerich S. Th22 cells in allergic disease. Allergo J Int. 2015;24(1):1-7.

21. Ito T, Hirose $\mathrm{K}$, Nakajima H. Bidirectional roles of IL-22 in the pathogenesis of allergic airway inflammation. Allergol Int. 2019;68(1):4-8.

22. Downie SR, Andersson M, Rimmer J, Leuppi JD, Xuan W, Akerlund A, et al. Symptoms of persistent allergic rhinitis during a full calendar year in house dust mite-sensitive subjects. Allergy Eur J Allergy Clin Immunol. 2004;59(4):406-14.

23. Juniper EF, Thompson AK, Ferrie PJ, Roberts JN. Validation of the standardized version of the Rhinoconjunctivitis Quality of Life Questionnaire. J Allergy Clin Immunol. 1999;104(2):364-9.

24. Nathan RA, Sorkness CA, Kosinski M, Schatz M, Li JT, Marcus P, et al. Development of the asthma control test: a survey for assessing asthma control. J Allergy Clin Immunol. 2004;113(1):59-65.

25. Juniper EF, Norman GR, Cox FM, Roberts JN. Comparison of the standard gamble, rating scale, $\mathrm{AQLQ}$ and SF-36 for measuring quality of life in asthma. Eur Respir J. 2001;18(1):38-44

26. Buysse DJ, Reynolds CF 3rd, Monk TH, Berman SR, Kupfer DJ. The Pittsburgh Sleep Quality Index: a new instrument for psychiatric practice and research. Psychiatry Res. 1989;28(2):193-213.

27. Degirmenci PB, Aksun S, Altin Z, Bilgir F, Arslan IB, Colak H, et al. Allergic rhinitis and its relationship with IL-10, IL-17, TGF- $\beta$, IFN- $\gamma$, IL 22, and IL-35. Dis Markers. 2018;2018:9131432.

28. Shahsavan S, Pirayesh A, Samani OZ, Shirzad H, Zamani MA, Amani S, et al. The relationship between IL-17A and IL-22 expression and clinical severity in patients with moderate/severe persistent allergic rhinitis. Am J Otolaryngol. 2019;40(2):173-8. https://doi.org/10.1016/j.amjoto.2018.12.009.

29. Farfariello V, Amantini C, Nabissi M, Morelli MB, Aperio C, Caprodossi S, et al. IL-22 mRNA in peripheral blood mononuclear cells from allergic rhinitic and asthmatic pediatric patients. Pediatr Allergy Immunol. 2011:22(4):419-23.

30. Zhu J, Cao Y, Li K, Wang Z, Zuo P, Xiong W, et al. Increased expression of aryl hydrocarbon receptor and interleukin 22 in patients with allergic asthma. Asian Pacific J Allergy Immunol. 2011;29(3):266-72.

31. Andersson CK, Adams A, Nagakumar P, Bossley C, Gupta A, De Vries D, et al. Intraepithelial neutrophils in pediatric severe asthma are associated with better lung function. J Allergy Clin Immunol. 2017;139(6):1819-1829. e11. https://doi.org/10.1016/j.jaci.2016.09.022

32. Zhao Y, Yang J, Gao YD, Guo W. Th17 immunity in patients with allergic asthma. Int Arch Allergy Immunol. 2010;151(4):297-307.

33. Fang P, Zhou L, Zhou Y, Kolls JK, Zheng T, Zhu Z. Immune modulatory effects of IL-22 on allergen-induced pulmonary inflammation. PLOS ONE. 2014;9(9):e107454.

34. Taube C, Tertilt C, Gyülveszi G, Dehzad N, Kreymborg K, Schneeweiss K, et al. IL-22 is produced by innate lymphoid cells and limits inflammation in allergic airway disease. PLOS ONE. 2011;6(7):e21799.

35. Nakagome K, Imamura M, Kawahata K, Harada H, Okunishi K, Matsumoto T, et al. High expression of IL-22 suppresses antigen-induced immune 
responses and eosinophilic airway inflammation via an IL-10-associated mechanism. J Immunol. 2011;187(10):5077-89.

36. Besnard A-G, Sabat R, Dumoutier L, Renauld J-C, Willart M, Lambrecht B, et al. Dual Role of IL-22 in allergic airway inflammation and its cross-talk with IL-17A. Am J Respir Crit Care Med. 2011;183(9):1153-63.

37. Wolk K, Witte E, Witte K, Warszawska K, Sabat R. Biology of interleukin-22. Semin Immunopathol. 2010;32(1):17-31.

38. Sherkat R, Yazdani R, Ganjalikhani Hakemi M, Homayouni V, Farahani $R$, Hosseini $M$, et al. Innate lymphoid cells and cytokines of the novel subtypes of helper T cells in asthma. Asia Pac Allergy. 2014;4(4):212-21.

\section{Publisher's Note}

Springer Nature remains neutral with regard to jurisdictional claims in published maps and institutional affiliations.
Ready to submit your research? Choose BMC and benefit from:

- fast, convenient online submission

- thorough peer review by experienced researchers in your field

- rapid publication on acceptance

- support for research data, including large and complex data types

- gold Open Access which fosters wider collaboration and increased citations

- maximum visibility for your research: over $100 \mathrm{M}$ website views per year

At BMC, research is always in progress.

Learn more biomedcentral.com/submissions 